\title{
Revisiting contemporary Irish migration: new geographies of mobility and belonging
}

\author{
Mary Gilmartin ${ }^{\mathrm{a} *}$ and Allen White ${ }^{\mathrm{b}}$ \\ ${ }^{a}$ Department of Geography, NUI Maynooth, Co. Kildare, Ireland; ${ }^{b}$ Department of Geography, \\ University College Cork, Ireland
}

\begin{abstract}
Though immigration has become one of the key issues facing Irish society, geographers in Ireland have been slow to respond. This is despite a long tradition of studying migration, particularly emigration, within Irish geography. This is even more surprising given recent developments within the discipline, as geography moves to assert its centrality to the study of international migration. This paper outlines the ways in which geographers in Ireland could contribute to broader debates about migration, both empirically and theoretically. It also introduces the five papers in this special issue of the journal, which provide a comprehensive overview of research on Irish migration, as well as detailed discussions of Irish migration to the UK, return migration and migration to Ireland from Poland, China and Nigeria.
\end{abstract}

Keywords: migration; immigration; Ireland

In a sense this is an obvious special edition of Irish Geography. Recent calls by geographers, both in Ireland (see Gilmartin et al. 2004, Kitchin 2004) and on the international stage (see Murphy et al. 2005) have stressed the importance of using our disciplinary strengths and traditions to address issues of contemporary social and political importance. To this end, how much more timely could it be to explore the dynamics and processes underpinning turn-of-the-century Ireland's migratory experiences? Migration - though more specifically, immigration - is one of the topics under discussion in the nation's airways, print media, homes, workplaces, cafes and pubs in Ireland today. Migration is one of the areas of research that has been traditionally well represented in Geography departments. As we say, it's obvious.

Yet when we examine the situation in more detail, the picture is a lot less straightforward. For one thing, this is not the first special collection of articles by geographers working in and on Ireland and migration. In 1991, the Geographical Society of Ireland published a series of papers presented to the conference of Irish Geographers the previous year. The book, Contemporary Irish migration (King 1991), contains 10 chapters from 11 contributors. It is possible to read these papers as a snapshot in time; a time when the terms 'migration' and 'Ireland' evoke images of emigrants leaving Ireland in their thousands (rather than immigrants entering the country in similar numbers). ${ }^{1}$ Of course, these papers were published when Ireland was on the cusp of its transformation from a country of emigration to a country of immigration. It is tempting (if a little unfair) to look through these papers for an awareness of the immanence of this transformation.

*Corresponding author. Email: mary.gilmartin@nuim.ie 
What is perhaps more surprising is that, in the period since 1991, Irish Geography has continued a protracted silence on migration, in particular a silence on the sustained immigration into Ireland in the period since 1995. Of course saying this depends on how one measures the contribution made by a discipline. The table of contents of Irish Geography is one place, but it does not capture all contributions by geographers on the topic of migration. Geographers have made important contributions into policy-related fora and reports (see Mac Éinrí 2001, 2002), and explored Ireland's contemporary migration for wider audiences than the readership of the Irish Geography (see Gilmartin 2006). However, it is undeniable that the journal of the Geographical Society of Ireland has published only two migration-themed papers in the last 15 years (see Jones 2003, Kelly 2005). While other disciplines have moved to publish high-quality research, exploring Ireland's recent immigration history (see, for example, Cronin 2004, Gray 2004, Kline 2004, Barrett et al. 2005, Grabowska 2005, Paris 2005, Wallen and Kelly-Holmes 2006, Ugba 2007), Ireland's human geographers have not, or so it would seem. The reasons why are probably manifold: it takes time to develop, oversee and execute high-quality research, the peer-review and publication of research papers is itself a protracted and lengthy affair and we are only still in the early stages of this remarkable demographic turnaround. That said, in light of the repeated calls for geographers to raise the public profile of the discipline - in Ireland and beyond - the lack of a body of geographic research on migration in (and specifically immigration into) Ireland is glaring. Since 1991 there has been a profound shift in Ireland's migration profile: from 'emigrant nursery' to immigrant destination, and Irish geographers have made an irregular contribution to the developments of theoretical and empirical research on this change. This is despite the long tradition, in Ireland and elsewhere, of exploring the dynamics of migration in human geography.

It is also significant that the relative silence on migration within Irish Geography has occurred during a period where the discipline of geography has asserted its centrality to the study of international migration. Since the early 1990s, geographers (and others) have begun to recognise the importance of the formation of migrants' social, political and cultural identities in any accounts of the factors shaping contemporary international migration flows (Boyle 2002). For Silvey and Lawson (1999) the re-theorisation of 'place' and 'migrant' offered by feminist and postcolonial scholarship in human geography point to ways in which the mutual constitution of place and identity (within hegemonic relations of power) shape and are shaped by patterns of mobility. In other words, critiques of viewing place and identity as bounded and fixed stress that these are contingent, unstable and criss-crossed by gendered, racialised and class-dependent relations of power. It thus follows that an analysis of movements of individuals or groups between places both shape and are shaped by these processes and relations (ibid.). In particular we point to the move in academic circles to reject accounts of international migration as a relatively permanent transition from one fixed point to another (mostly prompted by economically determined 'push' and 'pull' factors). Instead increasingly the 'international migrant' is replaced by the 'transnational migrant' or 'transmigrant' (Boyle 2002). Transnational accounts of migration stress the simultaneous, multi-stranded linkages and connections that join groups of people located in time-space within biographies of mobility and movement between various points of origin and destination, some of these movements being more permanent than others. Transnational theories offer human geographers a language and set of concepts that move beyond the objective categories of analysis employed in traditional migration theory (economic motivations and 'cultures' of emigration; push and pull factors, forced and voluntary migrations; micro and macro scales of analysis, etc.) (see Bailey 2001). Instead of the fixed certainties of the past, the complexity, dynamism and 
speed of contemporary international migration demands nothing less than a new theoretical paradigm. For Glick Schiller (1997) today's international migrants (or transmigrants) are qualitatively different to migrants from earlier eras. Immigrants to Ireland today are more likely to encompass both host and home societies. Their everyday lives go back and forth traversing national boundaries. They live dual lives, through two (or more) languages and being part of two (or more) households (see also Portes et al. 1999). There is much more to say about transnational migration, such as how 'new' it is, its relationship to diasporic formations and the extent to which emphasis on qualitative and ethnographic methods represents a continuation of a long research history in human geography (Silvey and Lawson 1999). What is undeniable is the extent to which transnational theory has reshaped research into international migration, and the extent to which geographers have been to the forefront of its reshaping.

Transnationalism clearly can be understood as produced by, and productive of, wider globalisation processes that restructure global flows and spaces of capital. In Ireland various social, political and economic factors as diverse as EU enlargement, the Good Friday Agreement and the national economy's position and performance within globalised hypermobile flows of capital have produced what Keohane and Kuhling (2004) have called a 'collision culture' between slower, settled, and more communal traditions and a faster, hypermobile, globalised and more individuated way of life. Despite these new realities and the pervasive sense that the nation-state is powerless to intercede within these globalised processes, researchers agree that the nation-state has a key role to play in shaping transnational migration and politics. This may take the form of constructing dispersed populations as de-territorialised nation-states or (re)organising the political and civil rights and claims of immigrants within particular national borders. In Ireland, the almost simultaneous passage of the 2004 Citizenship Referendum and the attempts by Irish politicians to lobby on behalf of undocumented Irish Americans demonstrate these contradictory pressures and processes. Thus contemporary analyses of transnational migration to (and from) Ireland must frame arguments and explanations within contextual and spatialised understandings of the role that the state plays in shaping these flows.

These contrasts and tensions - between the state's desire for fixity and the migrant's experience of mobility - are creating new geographies of belonging and exclusion. These geographies are particularly interesting in the case of Ireland, because of a long, sustained and (as the 1991 GSI Special Publication attests) relatively recent history of emigration. The theorisation of international migration provides little in the way of insight into the condition of contemporary Ireland: a former colony with a long history of migration, previously economically deprived, but now firmly located within a powerful and increasingly exclusionary Europe. Often, public statements on the topic of immigration to Ireland, particularly those that are aspirational, make explicit reference to Ireland's emigrant past. Memories of emigration are still recent enough to be raw, and contemporary immigration is frequently addressed through the lens of a difficult history. While that past is acknowledged, its implications for the treatment of contemporary immigrants gets obscured in a set of competing discourses about modern, wealthy, successful Ireland. Those discourses suggest that Ireland has a more pressing sense of priorities: preserving and accumulating wealth, and defending the concept and the borders of the European Union. As a consequence, recent initiatives on immigration - such as the Employment Permits Act and the Immigration, Residency and Protection Bill - favour immigrants with high earning potential. The implications of an immigration policy that creates hierarchies of immigrants based on income levels are significant. In particular, the ideology underpinning such legislation, seeing labour migration as temporary and 
expendable, denies the reality of the migrant experience through the decades and across a range of geographical contexts.

The papers in this special issue address the broad topic of Ireland and migration from a variety of perspectives. Piaras Mac Éinrí and Allen White reflect on recent research on migration in an Irish context. Their paper provides a comprehensive survey of the research produced so far on immigration into Ireland. In particular they point to specific gaps in our knowledge about immigration into Ireland, the lack of Irish geographers publishing research on immigration and the links between theory and the institutional contexts within which much of the research on immigration into Ireland is published.

Bronwen Walter, who in 1991 introduced gender as a key variable in researching Irish migration to Britain, reflects on the changes that have taken place since then in the patterns and characteristics of migration between Ireland and Britain. For hundreds of years, Ireland provided labour to Britain, and Irish communities have developed in a variety of towns and cities. Many of those communities have been depleted in recent years, losing recent immigrants who have returned to Ireland, and not receiving new immigrants as the migration stream from Ireland dries up. An important issue raised by Bronwen's paper and one that deserves further attention - relates to migration from Northern Ireland, often occluded because of the difficulties in terminology, but becoming increasingly significant.

The third paper, by Caitríona Ní Laoire, takes up the theme of return migration. Drawing on the findings of a larger research project, Caitríona's paper reflects on the experiences of Irish citizens who have returned to Ireland after years living in the UK, the US and elsewhere. Making use of a life narrative and biographical approach, Caitríona highlights the ways in which return migration to Ireland may be associated with a desire or compulsion to spend a particular part of the life course in Ireland, facilitated by the recent economic changes in Ireland.

The fourth and fifth papers, by Rebecca King-O'Riain and Julius Komolafe, deal explicitly with Ireland's newer migrant communities: Polish, Chinese and Nigerian. Rebecca King-O'Riain's paper, based on a series of interviews, considers the motivations and experiences of recent Polish and Chinese migrants to Ireland. Using theories of transnationalism, she argues that there are three general types of transnational orientations among these migrants: these are 'target earners', 'target learners', and 'trampoliners'. Julius Komolafe also focuses on motivations and experiences, in this instance of Nigerian migrants to Ireland. Based on interviews with Nigerians in Ireland and Nigeria, Julius develops a useful typology of Nigerian migration to Ireland, and highlights the differences in experiences and opportunities for migrants with different legal and residence status in Ireland; a point also highlighted by Rebecca in her discussion of Polish and Chinese migrants.

It is interesting to note that the majority of these papers - three in total - are substantially based on qualitative research. This may reflect a shift in social science methodologies, with an increasing acceptance of qualitative approaches. However, another reason is explicit in Bronwen and Caitríona's papers and implicit in Rebecca and Julius's papers: Irish statistics on immigration and emigration are, at best, patchy, and it is difficult to make claims about migration with any statistical certainty. This will no doubt change, as the mechanisms of state quantification catch up with recent demographic shifts in Ireland. For now, however, researchers are trying to fill significant gaps in our knowledge about migration to Ireland. Research, policy and activism on migration to Ireland thus, for the moment, is more likely to be reactive than visionary or aspirational.

Just as the 1991 migration issue, in retrospect, contains omissions and exclusions, it is important to acknowledge the obvious elisions in this collection of papers. There is no 
paper, and indeed there is precious little research, on Ireland's largest migrant community: people from the UK. There are no papers dealing with the spatial distribution of new migrants in Ireland, or with the politics of such an analysis. There are no papers explicitly examining immigration in relation to status - the experiences of asylum seekers and undocumented immigrants are undoubtedly different to those of working visa holders, and these differences are important to highlight. Similarly, there are no papers dealing with the relationship between immigration and particular employment sectors, such as agriculture, construction or medicine, or between patterns of immigration and the role and activities of recruitment agents and agencies. Questions of identity - for example, race, ethnicity, gender, sexuality - are also occluded. These are obvious areas for future research, and areas where geographers can make a significant contribution. In a broader context, these papers also focus on Ireland as a locus of investigation. It would be instructive to compare the experiences of Ireland to other 'new' countries of immigration, both within Europe (e.g. Spain and Italy) but also in Asia (Singapore, South Korea) and the Middle East (e.g. Israel).

As the debate in Ireland moves from immigration to integration, further challenges arise. The first challenge is to recognise that immigration to Ireland, rather than being a stand-alone and exceptional process, is a component, and outcome, of broader global processes. It is no coincidence that a high proportion of immigrants to Ireland from Nigeria are Catholic - this movement is linked to generations of Irish missionaries who made their homes there and became involved in that country's religious, social and cultural life, particularly through the provision of education. Similarly, migration movements from the Philippines need to be understood in terms of that country's policy of encouraged emigration, as well as specific efforts by recruitment agents working on behalf of Irish employers. The recent recruitment of nurses to work in Irish hospitals serves to incorporate Ireland into the global care chain in new ways. Previously a source of nursing labour, particularly for the UK, Ireland is now the latest destination for nurses from the Philippines and from Kerala in southern India (Yeates 2004, Brush and Vasupuram 2006). Linked to this is the realisation that, despite a focus on immigration, thousands of people continue to leave Ireland each year. Many do so as part of a working holiday visa experience - again, an under-researched area - but others leave Ireland for more problematic reasons: to escape violence or drugs, or because of limited economic opportunities. It is crucial to continue to make emigrants from Ireland visible, and to see their decisions as linked to broader spatial and social conditions in Irish society that affect immigrants as well as the settled community. The second challenge relates to the tendency, in Ireland, to see immigration as temporary and - rather like the "Celtic Tiger" - illusory. If immigration is constructed as temporary, then immigrants become a disposable resource, and our responsibilities to immigrants end when our need for their labour no longer exists. Evidence from a host of other countries - Germany, France, the US, the UK, for example - shows us that temporary migration rarely remains temporary. Designing policies around such an understanding will inevitably lead to future difficulties, both for first generation migrants and for their children and grandchildren. The third challenge relates to the discursive construction of legitimacy and illegitimacy in relation to immigration. Politicians and the media regularly brand particular groups of immigrants - asylum seekers, 'citizenship tourists', or economic migrants, for example - as problematic. The creation of migration hierarchies serves to dehumanise migrants, to deny the realities of their everyday lives, and to inhibit their possibilities for belonging. As researchers, it is important to recognise the barriers to 
belonging for migrants, and to highlight the role of discursive constructions in reifying categories of migrants.

This special issue is, we hope, the starting point for a more sustained engagement by geographers with migration and Ireland. We would like to thank the contributors for their willingness to respond to our requests for papers, and we would also like to thank Pádraig Carmody for supporting this initiative.

\section{Note}

1. The majority (six of ten) of these papers explore Ireland's changing position within a global and international migration order, sending emigrants all over the globe and creating Irish communities in the UK, the US, Australia and France (Breathnach and Jackson 1991, Grimes 1991, Mac Éinrí 1991, Strachan 1991, Walter 1991). The two papers (Kockel 1991, McGrath 1991) concerned with immigration into Ireland immediately stress the quantifiably negligible impact of these movements. The final two papers (Cawley 1991, Walsh 1991) explore migration within Ireland.

\section{References}

Bailey, A., 2001. Turning transnational: notes on the theorisation of international migration. International Journal of Population Geography, 7, 413-428.

Barrett, A., Bergin, A., and Duffy, D., 2005. The labour market characteristics and labour market impacts of immigrants in Ireland. Bonn: IZA.

Boyle, P., 2002. Population geography: transnational women on the move. Progress in Human Geography, 26 (4), 551-543.

Breathnach, P. and Jackson, J., 1991. Ireland, emigration and the new international division of labour. In: R. King, ed. Contemporary Irish migration, GSI Special Publications No. 6. Dublin: GSI, $1-10$.

Brush, B.L. and Vasupuram, R., 2006. Nurses, nannies and caring work: importation, visibility and marketability. Nursing Inquiry, 13 (3), 181-185.

Cawley, M., 1991. Patterns of rural-urban and urban-rural migration. In: R. King, ed. Contemporary Irish migration, GSI Special Publications No. 6. Dublin: GSI, 111-121.

Cronin, M., 2004. Babel atha cliath: the languages of Dublin. New Hibernia Review, 8 (4), 9-22.

Gilmartin, M., 2004. Geography in Ireland in transition - some comments. Irish Geography, 37 (2), 121-144.

Gilmartin, M., 2006. Ireland's ethnic make-up: the same but different. Irish Times, July 11.

Glick Schiller, N., 1997. The situation of transnational studies. Transnational processes/situated identities. Special issue of Identities: Global Studies in Culture and Power, 4, 2.

Grabowska, I., 2005. Changes in the international mobility of labour: job migration of Polish nationals to Ireland. Irish Journal of Sociology, 14 (1), 27-44.

Gray, B., 2004. Remembering a 'multicultural' future through a history of emigration: towards a feminist politics of solidarity across difference. Women's Studies International Forum, 4, 412-429.

Grimes, S., 1991. Post-war Irish immigration in Australia. In: R. King, ed. Contemporary Irish migration, GSI Special Publications No. 6. Dublin: GSI, 42-54.

Jones, R., 2003. Multinational investment and return migration in Ireland in the 1990s: a county-level analysis. Irish Geography, 36 (2), 153-169.

Kelly, D., 2005. Dublin's spatial narrative - the transition from essentially monocultural places to polycultural spaces. Irish Geography, 38 (2), 209-224.

Keohane, K. and Kuhling, C., 2004. Collision culture: transformations in everyday life in Ireland. Dublin: Liffey Press.

King, R., ed., 1991. Contemporary Irish migration. Dublin: Geographical Society of Ireland.

Kitchin, R., 2004. Geography in Ireland in transition. Irish Geography, 37 (2), 15-19.

Kline, B., 2004. The changing social environment of modern Ireland: immigration and the issues of politics, economics and security. Mediterranean Quarterly, 15 (4), 186-202.

Kockel, U., 1991. Countercultural migrants in the west of Ireland. In: R. King, ed. Contemporary Irish migration, GSI Special Publications No. 6. Dublin: GSI, 70-82.

Mac Éinrí, P., 1991. The Irish in Paris: an aberrant community. In: R. King, ed. Contemporary Irish migration, GSI Special Publications No. 6. Dublin: GSI, 32-41. 
Mac Éinrí, P., 2001. Immigration into Ireland: trends, policy responses, outlook. Cork: ICMS, UCC.

Mac Éinrí, P., 2002. The implications for Ireland and the UK arising from the development of recent EU policy on migration. In: Migration policy in Ireland: reform and harmonisation. Dublin: NCCRI, 38-55.

McGrath, F., 1991. The economic, social and cultural impacts of return. In: R. King, ed. Contemporary Irish migration, GSI Special Publications No. 6. Dublin: GSI, 55-69.

Murphy, A., et al., 2005. The role of geography in public debate. Progress in Human Geography, 29 (2), 165-193.

Paris, C., 2005. Housing and the migration turnaround in Ireland. Urban Policy and Research, 23 (3), 287-304.

Portes, A., Guarnizo, L.E., and Landolt, P., 1999. The study of transnationalism: pitfalls and promise of an emergent research field. Ethnic and Racial Studies, 22, 217-237.

Shuttleworth, I., 1991. Graduate emigration from Ireland: a symptom of peripherality? In: R. King, ed. Contemporary Irish migration, GSI Special Publications No. 6. Dublin: GSI, 83-95.

Silvey, R. and Lawson, V., 1999. Placing the migrant. Annals of the Association of American Geographers, 89 (1), 121-132.

Strachan, A., 1991. Post-war Irish migration and settlement in England and Wales. In: R. King, ed. Contemporary Irish migration, GSI Special Publications No. 6. Dublin: GSI, 21-31.

Ugba, A., 2007. African Pentecostals in twenty-first century Ireland: identity and integration, In: B. Fanning, ed. Immigration and Social Change in Ireland. Manchester: Manchester University Press.

Wallen, M. and Kelly-Holmes, H., 2006. 'I think they just think it's going to go away at some stage': policy and practice in teaching English as an additional language in Irish primary schools. Language and Education, 20 (2), 141-161.

Walsh, J., 1991. Inter-county migration in the Republic of Ireland: patterns and processes. In: R. King, ed. Contemporary Irish migration, GSI Special Publications No. 6. Dublin: GSI, 96-110.

Walter, B., 1991. Gender and recent Irish migration to Britain. In: R. King, ed. Contemporary Irish Migration, GSI Special Publications No. 6. Dublin: GSI, 11-20.

Yeates, N., 2004. Broadening the scope of global care chain analysis: nurse migration in the Irish context. Feminist Review, 77, 79-95. 